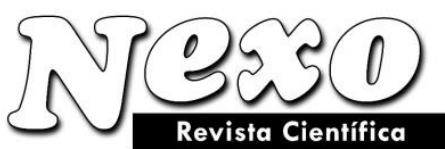

Vol. 34, No. 01, pp. 242-257/Marzo 2021

\title{
Calculation of active earth pressure on retaining walls with line surcharge effect and presentation of design diagrams in cohesive - frictional soils
}

\section{Cálculo de la presión de tierra activa en muros de retención con efecto de carga de línea y presentación de diagramas de diseño en suelos cohesivos - friccionales}

\author{
Mojtaba Ahmadabadi*, Mohammad Karim Faghirizadeh \\ Faculty Member at Shiraz Art Institute of High Education, Shiraz, Iran. \\ * Ahmadabadi.m@gmail.com , Faghirizadeh@gmail.com
}

(recibido/received: 05-January-2021; aceptado/accepted: 27-February-2021)

\begin{abstract}
In this study, a formulation and models have been proposed to calculate the active earth pressure on the wall and to determine the angle of failure wedge with line surcharge effect and taking into account the soil cohesion. The proposed method has the advantage of taking into account soil parameters such as cohesion, the angle of friction between the soil and the wall, the surcharge effect in the elasto-plastic environment, and the range that determines the critical surcharge. This paper presents dimensionless diagrams for different soil specifications and surcharges. According to these diagrams, it is easy to determine the distribution of excess pressure caused by surcharge, the distribution of the total active earth pressure on the wall, the angle of the failure wedge as well as the minimum and maximum active coefficient of the pressure with respect to surcharge distance. Furthermore, all soil parameters, surcharge and the results have been addressed. In general, the results indicated that increasing the angle of internal friction of the soil and cohesion would result to a nonlinear reduction in the active earth pressure coefficient, contrary to the line surcharge, which increases the active earth pressure of the soil and ultimately increases the active earth pressure coefficient. In this research, a diagram has been presented that expresses the surface that the active earth pressure coefficient changes with respect to the surcharge distance. The lower limit of each graph expresses the minimum active earth pressure coefficient (kas (min)) at the minimum surcharge distance, whereas the upper limit indicates the maximum active earth pressure coefficient $(\operatorname{kas}(\max ))$ at the maximum surcharge distance from the wall. Comparison of the results of the proposed method with previous methods, codes and numerical software shows that in general, the proposed method is able to simplify the analysis of walls with surcharge effect in cohesivefrictional soils. In addition to the formulation and diagrams, a computer program in MATLAB software has been written. Using the results of these codes, the pressure on the wall with the linear surcharge effect, angle of failure wedge and pressure distribution on the wall in the cohesivefrictional soils can be calculated for all scenarios.
\end{abstract}

Keywords: Active earth pressure, Line surcharge, Angle of internal friction, Angle of failure wedge, Retaining wall. 


\section{RESUMEN}

En este estudio se ha propuesto una formulación y modelos para calcular la presión de tierra activa en el muro y determinar el ángulo de falla de la cuña con efecto de sobrecarga de línea y teniendo en cuenta la cohesión del suelo. El método propuesto tiene la ventaja de tener en cuenta parámetros del suelo como la cohesión, el ángulo de fricción entre el suelo y la pared, el efecto de sobrecarga en el ambiente elastoplástico y el rango que determina la sobrecarga crítica. Este artículo presenta diagramas adimensionales para diferentes especificaciones de suelo y sobrecargas. De acuerdo con estos diagramas, es fácil determinar la distribución del exceso de presión causado por la sobrecarga, la distribución de la presión de tierra activa total en el muro, el ángulo de la cuña de falla así como el coeficiente activo mínimo y máximo de la presión con respecto a la distancia de sobrecarga. Además, se han abordado todos los parámetros del suelo, la sobrecarga y los resultados. En general, los resultados indicaron que el aumento del ángulo de fricción interna del suelo y la cohesión daría como resultado una reducción no lineal en el coeficiente de presión de tierra activa, contraria a la sobrecarga lineal, lo que aumenta la presión de tierra activa del suelo y finalmente aumenta el coeficiente de presión de tierra activa. En esta investigación se ha presentado un diagrama que expresa la superficie que cambia el coeficiente de presión de tierra activa con respecto a la distancia de sobrecarga. El límite inferior de cada gráfico expresa el coeficiente mínimo de presión de tierra activa (kas (min)) a la distancia mínima de sobrecarga, mientras que el límite superior indica el coeficiente máximo de presión de tierra activa (kas (max)) a la distancia máxima de sobrecarga del muro. La comparación de los resultados del método propuesto con métodos anteriores, códigos y software numérico muestra que, en general, el método propuesto es capaz de simplificar el análisis de muros con efecto de sobrecarga en suelos cohesivo-friccionales. Además de la formulación y los diagramas, se ha escrito un programa informático en software MATLAB. Usando los resultados de estos códigos, la presión en la pared con el efecto de sobrecarga lineal, el ángulo de cuña de falla y la distribución de la presión en la pared en los suelos cohesivofriccionales se pueden calcular para todos los escenarios.

Palabras claves: Presión de tierra activa, Sobrecarga de línea, Ángulo de fricción interna, Ángulo de cuña de falla, Muro de contención.

\section{INTRODUCTION}

Important factors influence the active earth pressure on the wall. Various researchers have so far investigated such parameters. None of the methods presented by the researchers has addressed all of these parameters, and that each of the proposed methods suffers from a certain level of limitations. One of the parameters not taken into account is the cohesion or angle of friction between the soil and the wall. In methods where most of the parameters are considered, the proposed method does not completely respond to the designer's need, for example, it is either not a seismic, or does not present the distribution of stress and the location of the force effect. In the full range of methods presented in recent years, water cavity pressure, surcharge and soil layering are often neglected, or that the proposed method is not able to calculate the displacement of the wall.

Soil active pressure is calculated in various ways, such as the infinite method (Coulomb, 1773), plasticity theories (Rankine, 1857), elasticity theories, experimental methods and in-vitro methods. In retaining walls with surcharge, to calculate the excess pressure caused by surcharge on the retaining walls, one of the approaches is that first, the surcharge effect on the embankment is separately calculated using the elasticity theory. Then the results are combined with the results of wall analysis in the absence of surcharge. With this approach, (Braja M. Das, 1992), referring to the difference in the results of the elastic method for calculating the effect of surcharge with real values, provided relations with the assumption of elastic behavior. Further, with this approach, the (AASHTO, 2002) and U.S. Army Crops (2005) have provided an analytical method for calculating the soil lateral pressure. The other approach is to simultaneously consider the effect of soil and linear surcharge. 
With this approach, using Coulomb theory,(Motta, 1994) and (Greco, 1999, 2003, 2005, 2006), examined the effect of surcharge on active pressure on unarmored retaining walls and presented an analytical method for calculating the pressure and effect point. In (Cheng, 2003) and (B. M. Das \& Puri, 1996) presented lateral soil pressure in cohesive soils.

(YILDIZ, OZYAZICIOGLU, \& OZKAN, 2010) calculated the pressure on the wall with the effect of strip surcharge and using the neural network based on finite element method data. (Basha \& Basudhar, 2010), using the limit equilibrium method taking into account Logarithmic spiral failure wedge, investigated the stability of reinforced soil structures under the effect of surcharge in seismic conditions. According to (M. Ahmadabadi \& Ghanbari, 2009), (Ghanbari \& Taheri, 2012) calculated the pressure on the wall and the reinforcing force with the effect of surcharge. Furthermore, (Esmaeili \& Fatollahzadeh, 2013), using the first approach, calculated the lateral pressure on wall with elasticity assumptions due to the railroad load. (Ouyang, Xu, He, Luo, \& Wu, 2013) proposed a generalized limit equilibrium method for solving the active pressure behind a retaining wall and considered the failure wedge without any hypothetical aspect.

(Farzaneh, Askari, \& Fatemi, 2014) presented a two-dimensional analysis method with the simultaneous effect of soil weight and surcharge and presented their results as design charts. The limitation of this method is also not to consider soil cohesion. (Han, Gong, \& Zhang, 2016), using the finite element method, introduced the seismic pressure on the wall in layer soils. The researchers presented two types of linear and curve failure wedges and evaluated the effects of friction angle between soil and wall and cohesion. The results showed that for a small friction angle, the failure surface is flat.

(Mojtaba Ahmadabadi \& Faghirizadeh, 2017) calculated the most seismic pressure on the wall for a circular failure wedge, whose values are more critical than the linear failure wedge. Among the limitations are the complexity of the formulation and the need for coding in MATLAB software. (Pain, Choudhury, \& Bhattacharyya, 2017) investigated the stability of the retaining wall with a log-spiral failure wedge and in the reinforced soil. The limitation of this method is to ignore soil cohesion and the angle of friction between the soil and the wall and the effect of surcharge. In (Mojtaba Ahmadabadi \& Faghirizadeh, 2017) method, formulation was presented for retaining wall with linear surcharge and non-cohesive soils, which includes $3 \mathrm{n}$ equations and $3 \mathrm{n}$ unknowns. Using such formulation, the active pressure coefficient, the angle of the failure wedge and the location of the resultant force at the level of failure with the effect of a linear surcharge is obtained. One of the limitations of the above method is ignoring soil cohesion. For this purpose, in this study, by elaborating (Mojtaba Ahmadabadi \& Faghirizadeh, 2017) method and taking into account the soil cohesion, a more complete formulation and functional diagrams were presented to calculate active pressure on the wall.

Gupta and Sawant (2019) presented a method for calculating the seismic pressure of artillery wall. It should be noted that they ignored the friction angle between the soil and the wall as well as the effect of surcharge and did not present the results of the stress distribution on the wall and presented their results for various confidence coefficients.

\begin{tabular}{llll}
\hline Nomenclature & & $\mathrm{k}_{\mathrm{as}(\mathrm{min})}$ & $\begin{array}{l}\text { The minimum of active earth pressure } \\
\text { coefficient in minimum surcharge distance } \\
\text { (dimensionless) }\end{array}$ \\
\hline $\mathrm{F}_{\mathrm{i}}$ & $\begin{array}{l}\text { resultant of shear force and vertical } \\
\text { force at the surface of failure }\end{array}$ & $\mathrm{k}_{\mathrm{as}(\mathrm{max})}$ & $\begin{array}{l}\text { The maximum of active earth pressure } \\
\text { coefficient in minimum surcharge distance } \\
\text { (dimensionless) }\end{array}$ \\
\hline $\mathrm{H}$ & height of wall $(\mathrm{m})$ & $\mathrm{c}$ & cohesion of soil (kPa) \\
\hline $\mathrm{K}_{\mathrm{a}}$ & $\begin{array}{l}\text { Active earth pressure coefficient } \\
\text { without surcharge (dimensionless) }\end{array}$ & $\mathrm{x}$ & distance of surcharge from the wall (m) \\
\hline
\end{tabular}




\begin{tabular}{|c|c|c|}
\hline $\mathrm{K}_{\mathrm{aq}}$ & $\begin{array}{l}\text { coefficient of active pressure from } \\
\text { the surcharge (dimensionless) }\end{array}$ & $\begin{array}{l}\text { distance of force } F \text { to Heels of the Wall } \\
(\mathrm{m})\end{array}$ \\
\hline $\mathrm{K}_{\mathrm{as}}$ & $\begin{array}{l}\text { Active earth pressure coefficient } \\
\text { with the effect of surcharge } \\
\text { (dimensionless) }\end{array}$ & Greek letters \\
\hline $\mathrm{Q}$ & linear surcharge $(\mathrm{kN} / \mathrm{m})$ & Angle of failure wedge $\left({ }^{\circ}\right)$ \\
\hline $\mathrm{P}_{\mathrm{a}}$ & $\begin{array}{l}\text { Active earth pressure without } \\
\text { surcharge }(\mathrm{kN} / \mathrm{m})\end{array}$ & $\begin{array}{l}\text { Angle of failure wedge without } \\
\text { surcharge }\left(^{\circ}\right)\end{array}$ \\
\hline $\mathrm{P}_{\mathrm{aq}}$ & $\begin{array}{l}\text { resultant lateral earth pressure from } \\
\text { the surcharge }(\mathrm{kN} / \mathrm{m})\end{array}$ & $\begin{array}{l}\text { Angle of failure wedge on the location of } \\
\text { the effect of surcharge }(\circ)\end{array}$ \\
\hline$P_{a s}=P_{a}$ surcharge & $\begin{array}{l}\text { Active earth pressure with the } \\
\text { effect of surcharge }(\mathrm{kN} / \mathrm{m})\end{array}$ & $\begin{array}{l}\text { Angle of failure wedge with the effect of } \\
\text { surcharge }(\circ)\end{array}$ \\
\hline$P_{i}$ & $\begin{array}{l}\text { Active pressure on wall in the } i \text { th } \\
\text { wedge }\end{array}$ & $\begin{array}{l}\text { Angle of failure wedge in the } i \text { th } \\
\text { experimental wedge (o) }\end{array}$ \\
\hline $\mathrm{Ni}$ & $\begin{array}{l}\text { Normal force on failure surface for } \\
\text { ith wedge }(\mathrm{kN})\end{array}$ & Total unit weight $(\mathrm{kN} / \mathrm{m} 3)$ \\
\hline $\mathrm{Si}$ & $\begin{array}{l}\text { shear force on failure surface for ith } \\
\text { wedge }(\mathrm{kN})\end{array}$ & $\begin{array}{l}\text { friction angle between wall and backfill } \\
\text { soil }\left({ }^{\circ}\right)\end{array}$ \\
\hline $\mathrm{W}_{\mathrm{i}}$ & weight of ith slice $(\mathrm{kN})$ & angle of internal friction of soil $\left(^{\circ}\right)$ \\
\hline
\end{tabular}

\section{MATERIALS AND METHODS}

Proposed Formulation for the calculation of pressure on retaining wall with the effect of linear surcharge in cohesive-frictional soil:

In this paper, with the expansion of (Mojtaba Ahmadabadi \& Faghirizadeh, 2017) method and taking into account soil cohesion, the number of unknowns would vary from three to four, which requires four equations as follows.

$$
\begin{gathered}
\sum F_{x_{i}}=0 \longrightarrow P_{i} \cos \delta+S_{i} \cos \beta_{i}-N_{i} \sin \beta_{i}=0 \\
\sum F_{y_{i}}=0 \longrightarrow N_{i} \cos \beta_{i}+S_{i} \sin \beta_{i}+P_{i} \sin \delta-W_{i}-q=0 \\
\sum M_{o_{i}}=0 \longrightarrow-\frac{P_{i} H}{3} \cos \delta-\frac{W_{i} H}{3 \tan \beta_{i}}+N_{i} \cdot x_{F i}-q \cdot x=0 \\
S_{i}=\left[N_{i} \tan \phi+c \frac{H}{\sin \left(\beta_{i}\right)}\right]
\end{gathered}
$$

By solving the above four equations for each test wedge, four unknowns include $\mathrm{Pi}, \mathrm{Ni}, \mathrm{Si}$ and $\mathrm{xFi}$ are obtained for the ith failure wedge $(\beta \mathrm{i})$. Now in the proposed formulation to determine the angle of the failure wedge, the amount of active pressure on the wall is calculated for different angle failures. The angle that produces the maximum active pressure is recorded as the angle of the failure wedge. $\mathrm{Pa}$ is active pressure of the soil without surcharge indicate by $\beta 1$, Pas is active soil pressure with the effect of linear surcharge indicate by $\beta 3$ and Paq is excess pressure on the wall under linear surcharge.

$$
\vec{P}_{a s}=\vec{P}_{a}+\vec{P}_{a q}
$$

Considering the surcharge distance from the wall, we consider three modes for calculating the pressure on the wall $(\mathrm{Pi})$. 
Mode 1: If the linear surcharge distance from the wall is less than $x \leq \frac{H}{\tan \beta_{3}}$, the active pressure on the wall is obtained in accordance with equation (6), below.

$$
x \leq \frac{H}{\tan \beta_{3}} \longrightarrow P=P_{a s}=P_{a_{\text {surcharge }}}
$$

Mode 2: If the linear surcharge distance is equal to the value $\frac{H}{\tan \beta_{3}} \leq x \leq \frac{H}{\tan \beta_{1}}$, in this case, by placing the angle $\beta 2$ in equations 1 to 4 , the amount of pressure on the wall can be obtained in accordance with equation 8 .

$$
\begin{gathered}
\beta_{2}=\operatorname{Arctan} \frac{H}{x} \\
\frac{H}{\tan \beta_{3}} \leq x \leq \frac{H}{\tan \beta_{1}} \longrightarrow P=P_{\beta_{2}} \geq P_{a} \\
x \geq \frac{H}{\tan \beta_{1}},
\end{gathered}
$$

Mode 3: If the linear surcharge distance from the wall is greater than $x \geq \frac{H}{\tan \beta_{1}}$, it states that the existence of a linear surcharge on the wall is ineffective, and in order to calculate the pressure on the wall, one can consider the amount of surcharge equal to zero in equations 1 to 4 , and equation 9 is presented.

$$
\frac{H}{\tan \beta_{1}} \leq x \longrightarrow P=P_{a}
$$

Now, three types of active soil pressure coefficients can be defined as follows.

$$
\begin{aligned}
K_{a} & =\frac{P_{a}}{\frac{1}{2} \gamma H^{2}} \\
K_{a s} & =\frac{P_{a s}}{\frac{1}{2} \gamma H^{2}} \\
K_{a q} & =\frac{P_{a q}}{\frac{1}{2} \gamma H^{2}}
\end{aligned}
$$

\section{RESULTS AND DISCUSSION}

\subsection{Functional diagrams}

In order to provide design diagrams, changes in the soil friction angle, linear surcharge, friction angle between the soil and the wall and cohesion have been investigated. Also, the active pressure coefficient (Kas) has been used to make the diagrams dimensionless. As shown in Figures 1 to 3, increasing the angle of internal friction of the soil and cohesion reduce the Kas coefficient in a nonlinear way i.e. unlike the 
linear surcharge, which increases the active pressure of the soil and ultimately increases the Kas coefficient. Using these three diagrams, one can obtain pressure on the wall for all the soil parameters with surcharge and even without the effect of surcharge. It should be noted that for other soil parameters, one could use interpolation method or refer to equations or use MATLAB program codes.

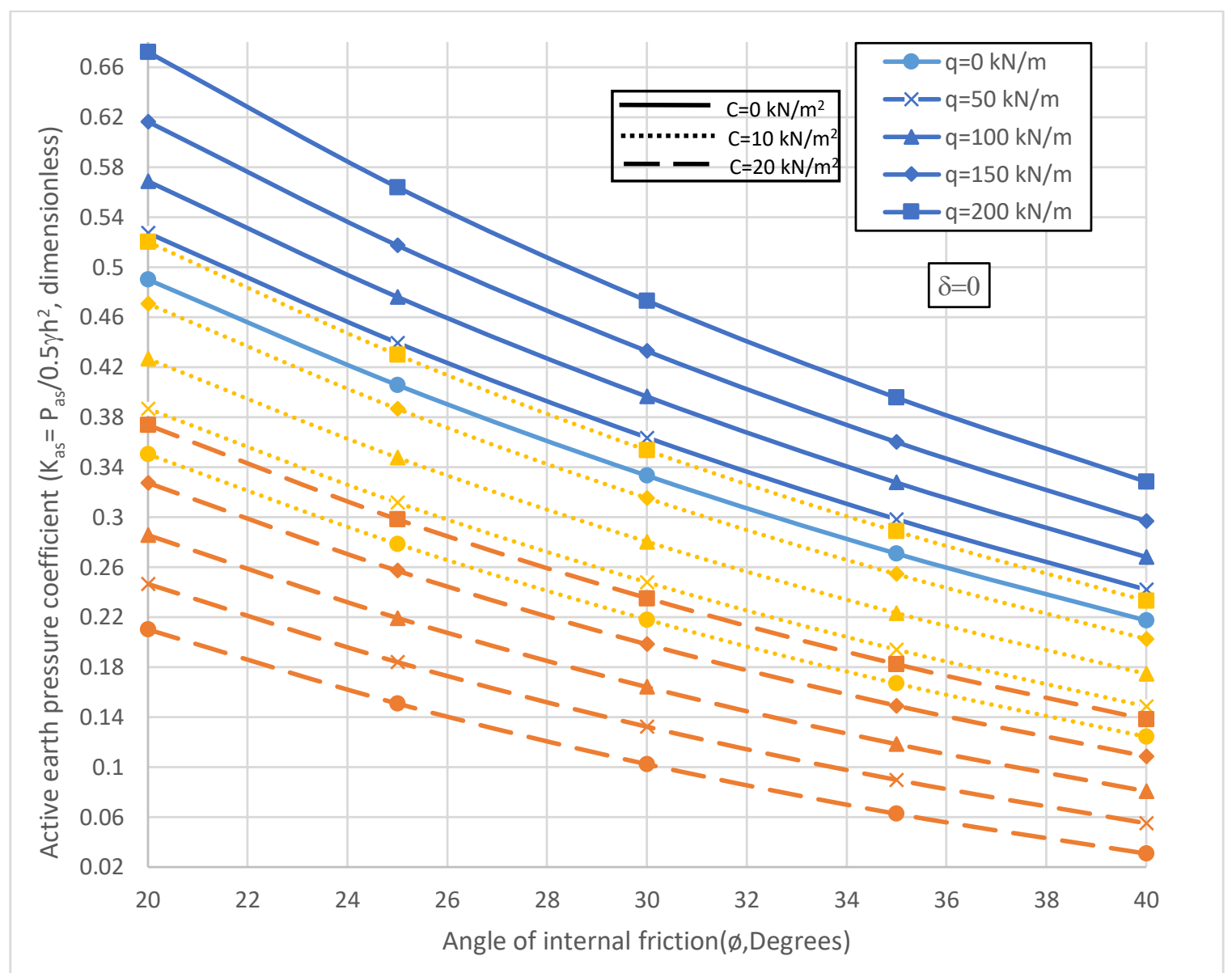

Figure 1: Variation in the active pressure coefficient (Kas) against the variation of the soil friction angle for different values of cohesion and linear surcharge for $\delta=0$ 


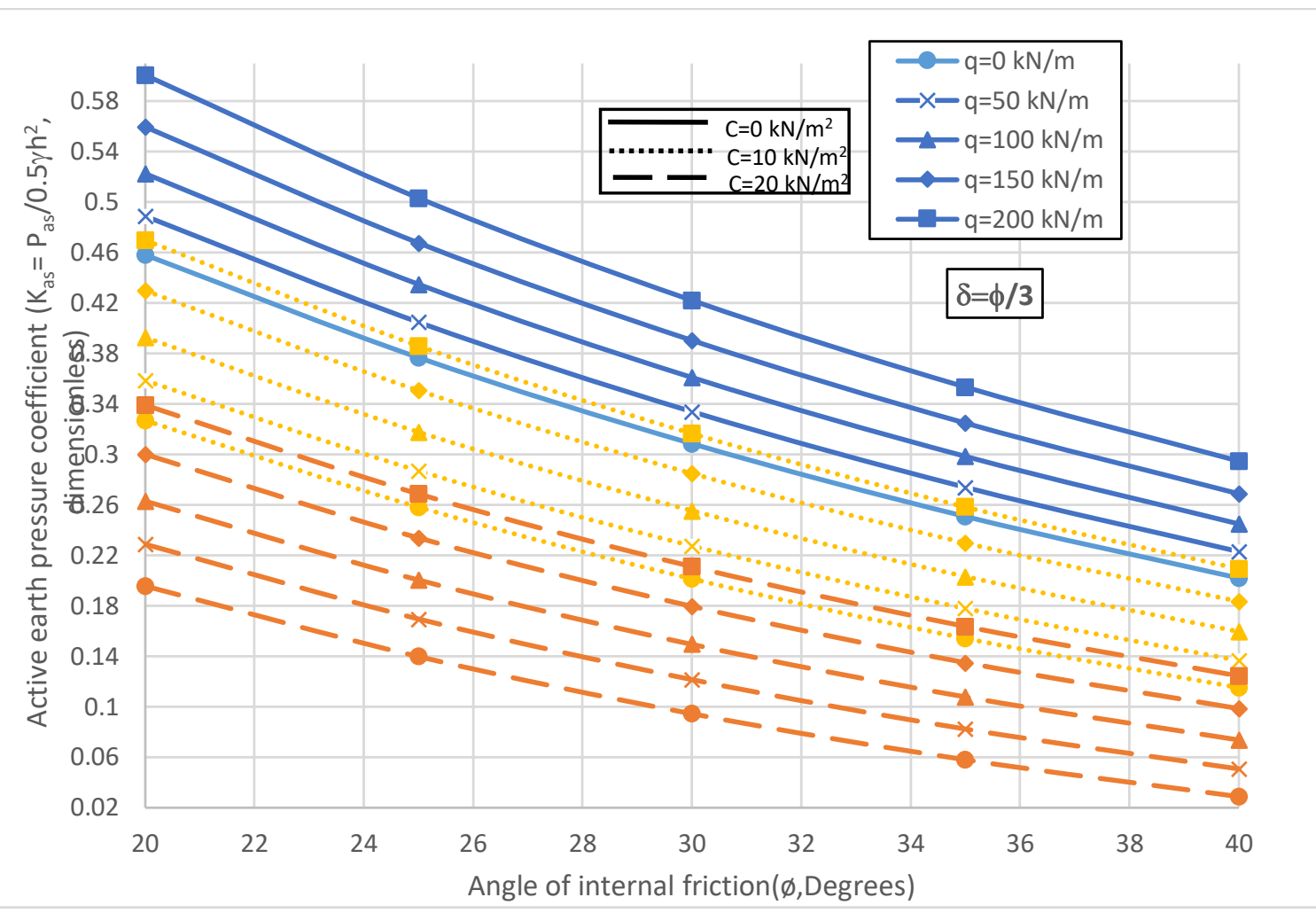

Figure 2: Variation in the active pressure coefficient (Kas) against the variation in the angle of soil frictional for different values of cohesion and linear surcharge for $\delta=\phi / 3$

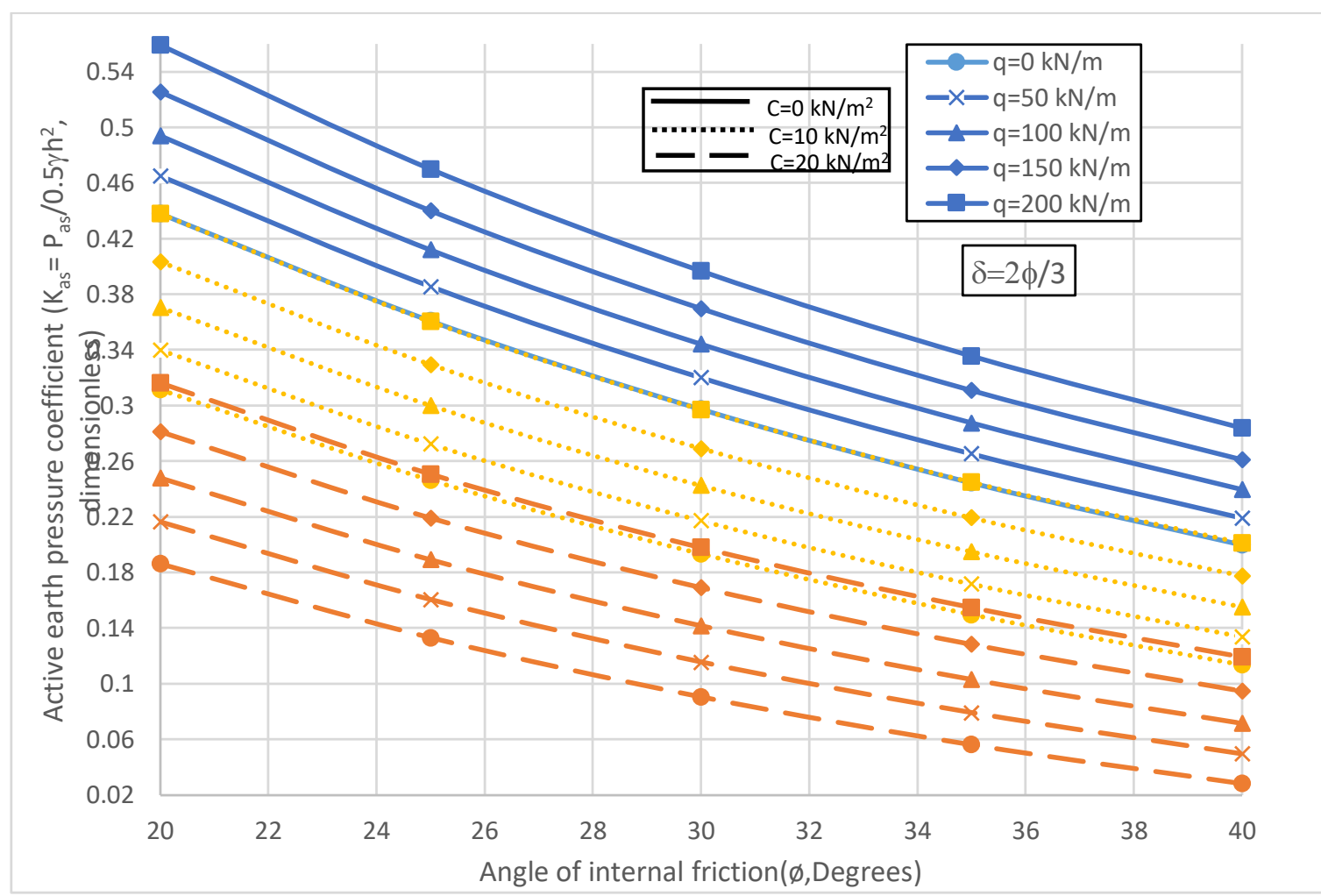

Figure 3: Variation of the active pressure coefficient (Kas) against the variation of the angle of soil friction for different values of cohesion and linear surcharge for $\delta=2 \phi / 3$. 
Figure 4 shows the surcharge distance from the wall. For this purpose, the variation of the active pressure coefficient (kas) against the variation in the surcharge distance from the wall is plotted. As the surcharge distance from the wall is extended, the pressure on the wall decreases. These variations are plotted for surcharges of 100 and $200 \mathrm{kN} / \mathrm{m}$, the cohesion of 0 and $20 \mathrm{kN} / \mathrm{m} 2$ as well as the friction angle of 20 to 40 degrees. These variations start with a surcharge separation from the wall from a maximum limit and end at a minimum. By increasing the angle of internal friction of the soil, the maximum impact distance of the surcharge is reduced. In addition, with the increase for surcharge, the pressure on the wall increases, and the distance of the surcharge results in the reduction of difference and eventually becomes zero.

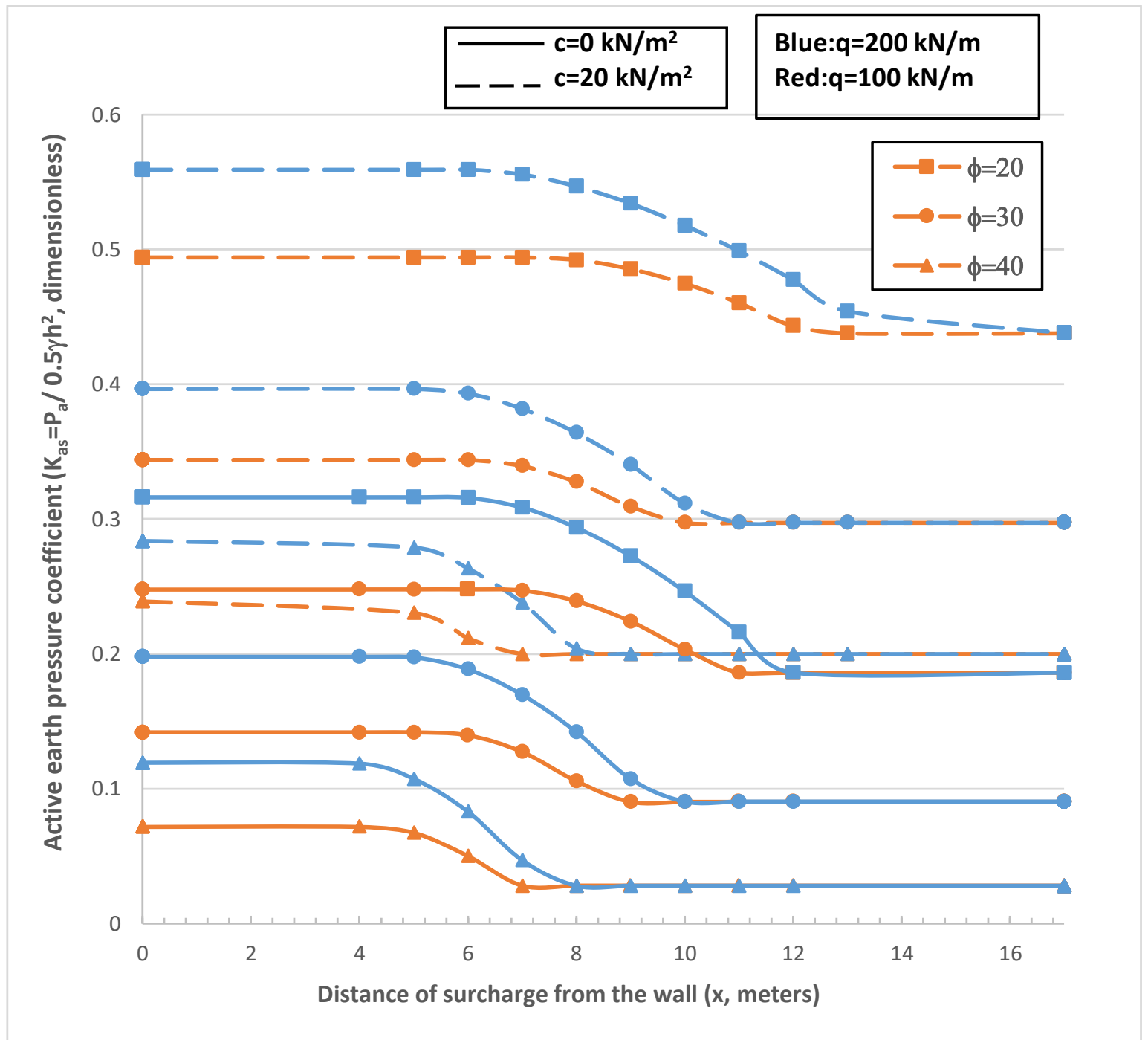

Figure 4: variations in the active pressure coefficient (Kas) against the variation of surcharge distance from the wall for different values of the angle of internal friction of the soil and the cohesion and linear surcharge

Figure 5 shows the surface that the active pressure coefficient changes with respect to the surcharge distance. The lower limit of each diagram expresses the minimum active pressure coefficient (kas (min)) at the minimum surcharge distance, and the upper limit indicates the maximum active pressure coefficient (kas $(\max ))$ at the maximum surcharge distance of the wall. Charts are plotted for 4 linear surcharge and cohesion values of 0,10 and 20, and interpolation can be used for other values. 


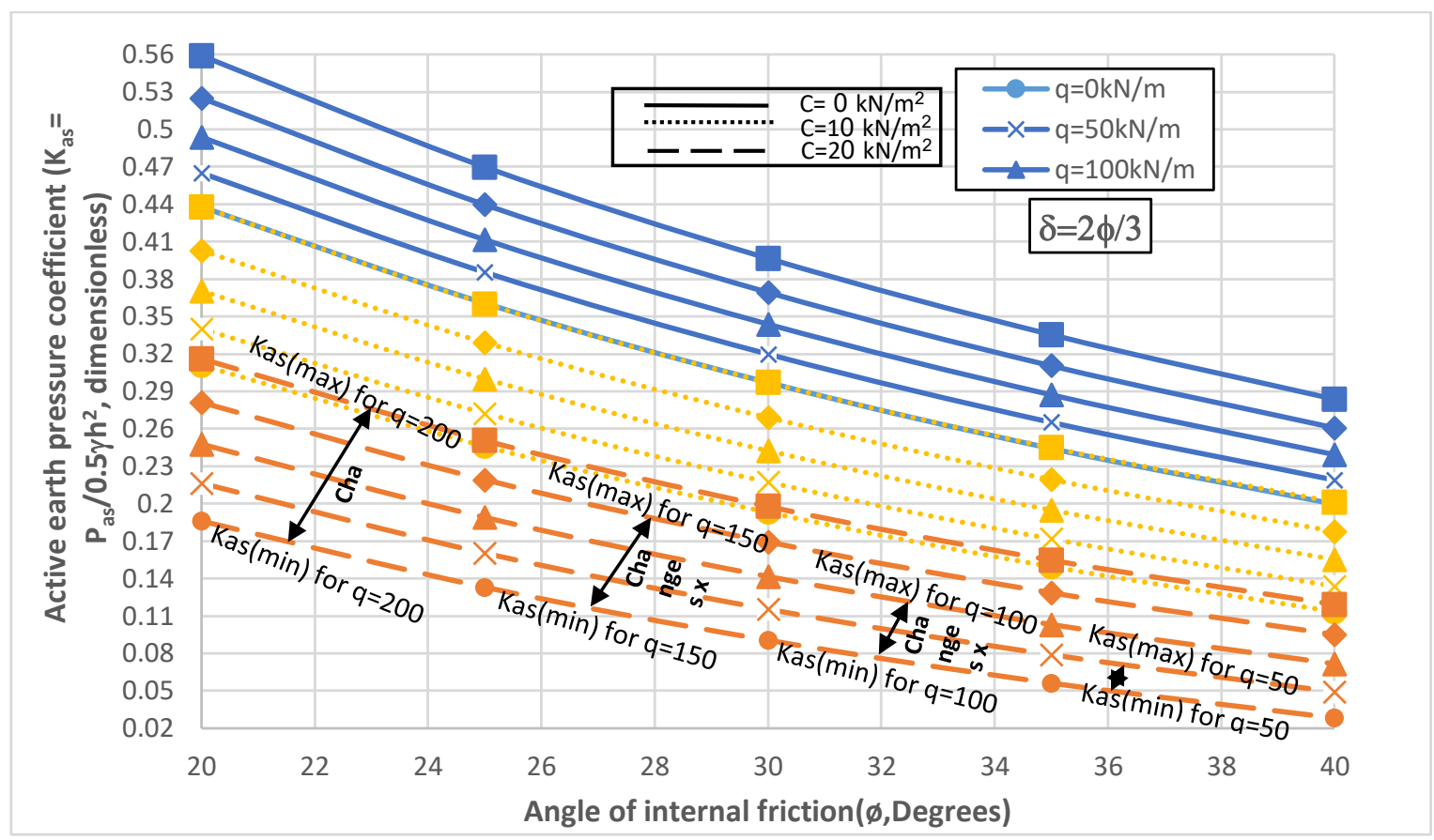

Figure 5: Maximum and minimum active pressure coefficient (Kas) with respect to the change of surcharge distance for different values of linear surcharge and cohesion

3.2. Determination of angle of failure wedge with linear surcharge effect in cohesive-frictional soils:

The angle giving the maximum active pressure is recorded as the angle of the failure wedge. In Fig. 6, the variations in the angle of the failure wedge are plotted against the changes in the angle of internal friction of the soil. Increasing the linear surcharge, the angle of internal friction of the soil and cohesion increase the angle of the failure wedge.

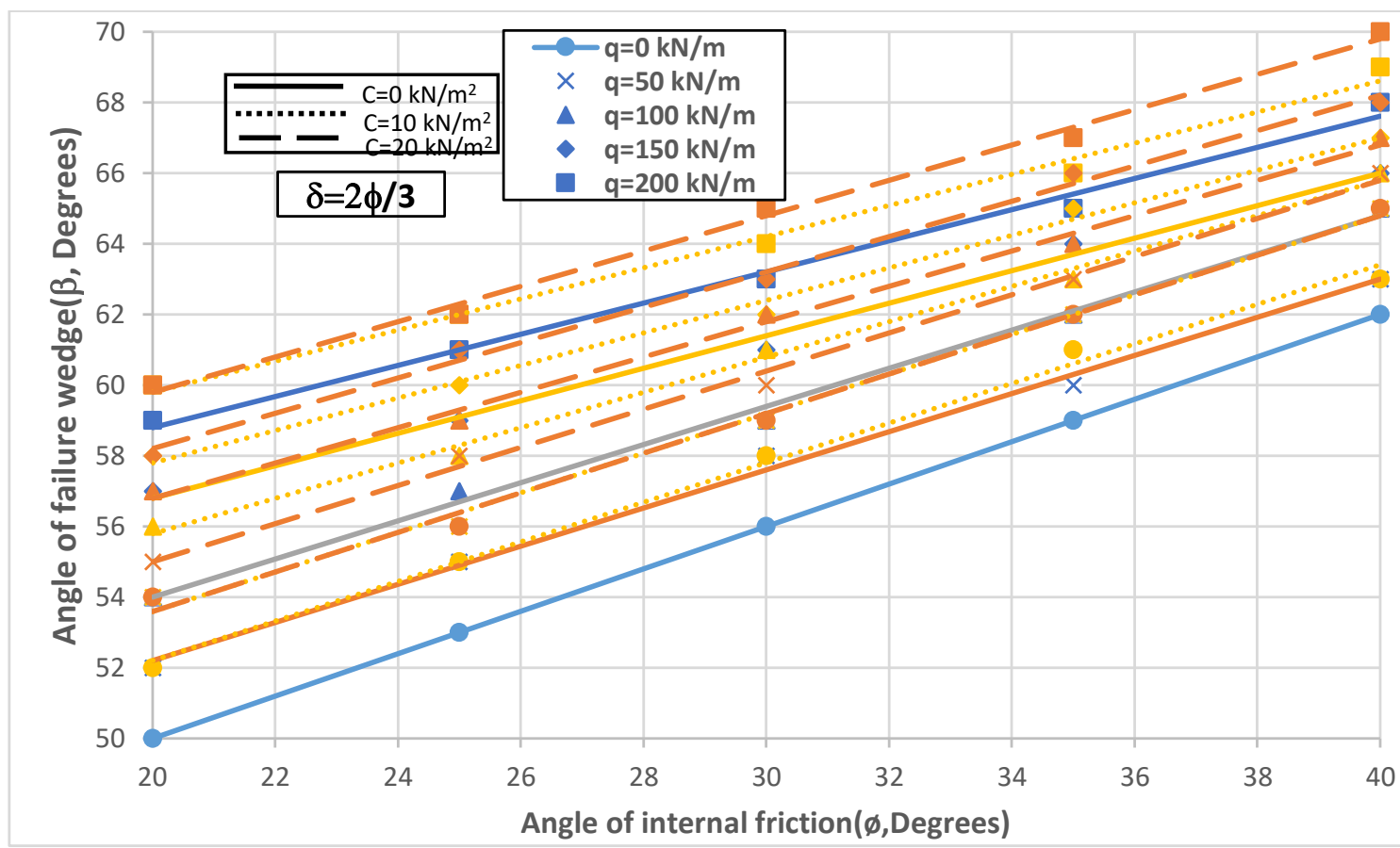

Figure 6: Variations of the angle of failure wedge against the variations of the angle of internal friction of soil for different values of linear surcharge and cohesion 
3.3. Distribution of stresses on walls with linear surcharge effect in cohesive-frictional soil:

In Figures 7 to 10, the distribution of stress is plotted for different values of the angle of internal friction, cohesion and linear surcharge. In Figure 7, the excess pressure distribution due to surcharge is plotted, which can be obtained by calculating the surface area of this diagram, which can be due to excess surcharge (Paq). In Figure 8, the distribution of total stress, including soil pressure and surcharge effect, is plotted. By calculating the surface below this diagram, one can obtain the total pressure of the wall (Pas). Increasing the angle of internal friction of the soil will always reduce the stress distribution.

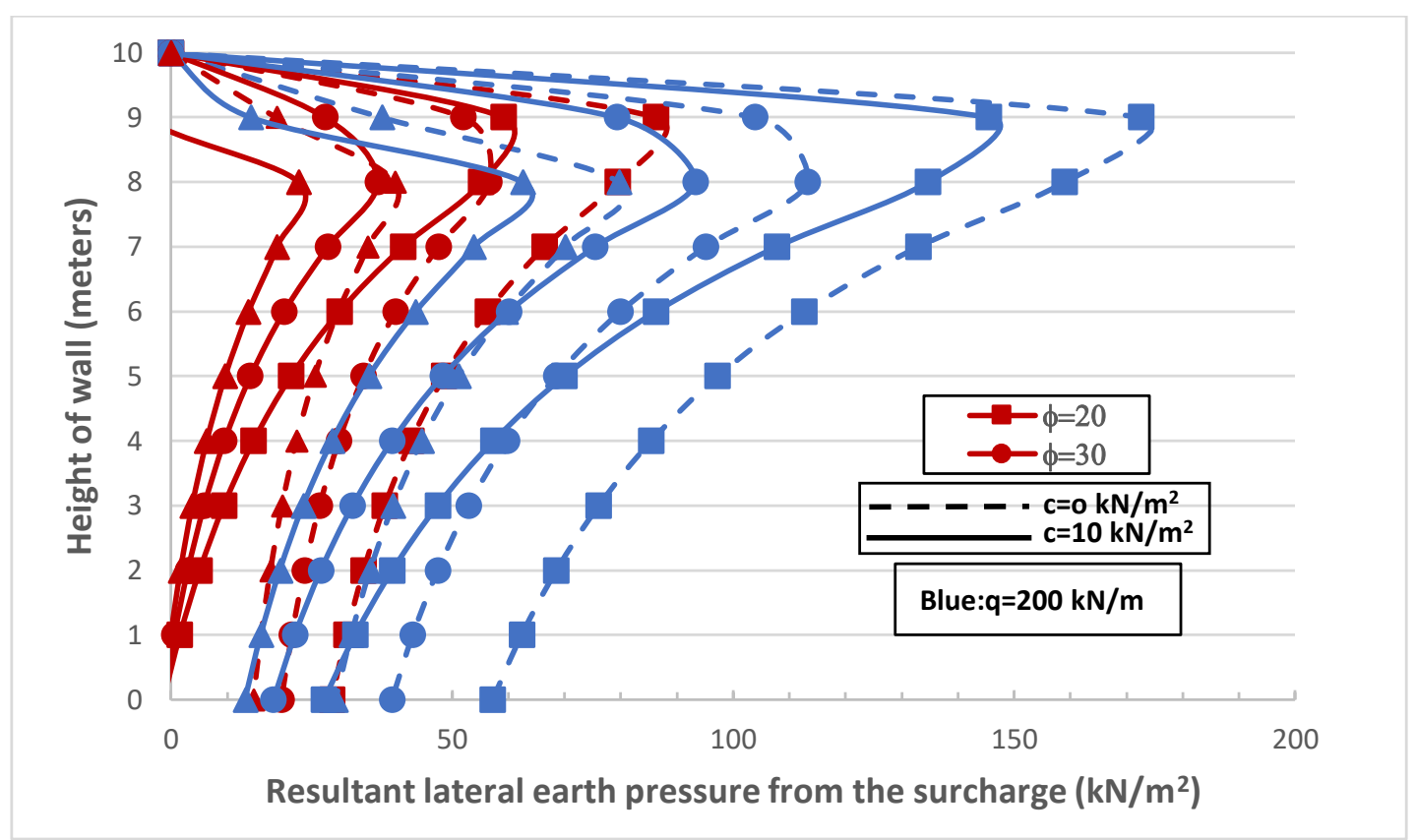

Figure 7: Excess pressure distribution due to surcharge for different values of the angle of internal friction of the soil and the cohesion and linear surcharge

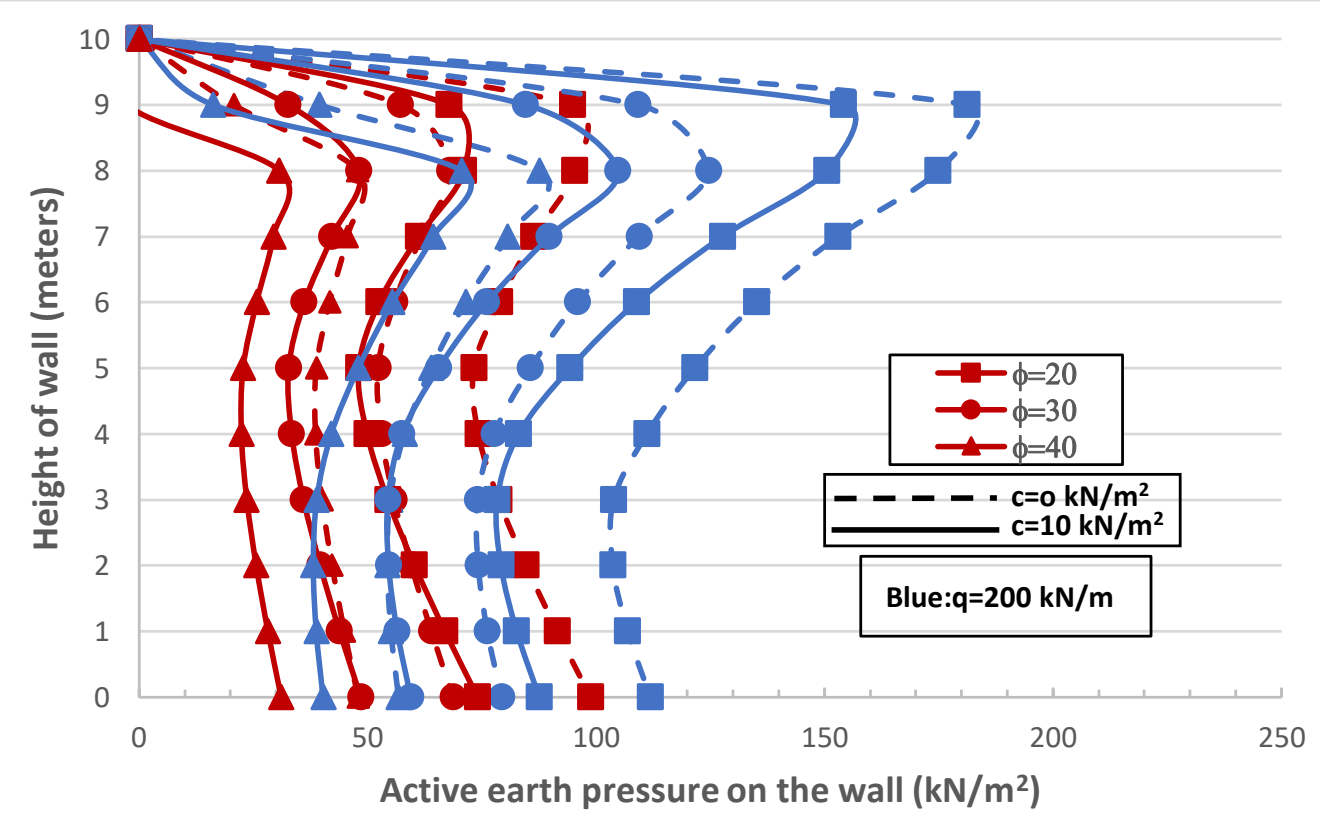

Figure 8: Distribution of the total active pressure on the wall for different values of the angle of the internal friction of the soil and the cohesion and linear surcharge 
In Figs. 9 and 10, the distribution of the total active pressure on the wall is plotted with linear surcharge changes and the angle of internal friction of the soil. Increased surcharge causes inflation and non-linearity in the stress distribution diagram.

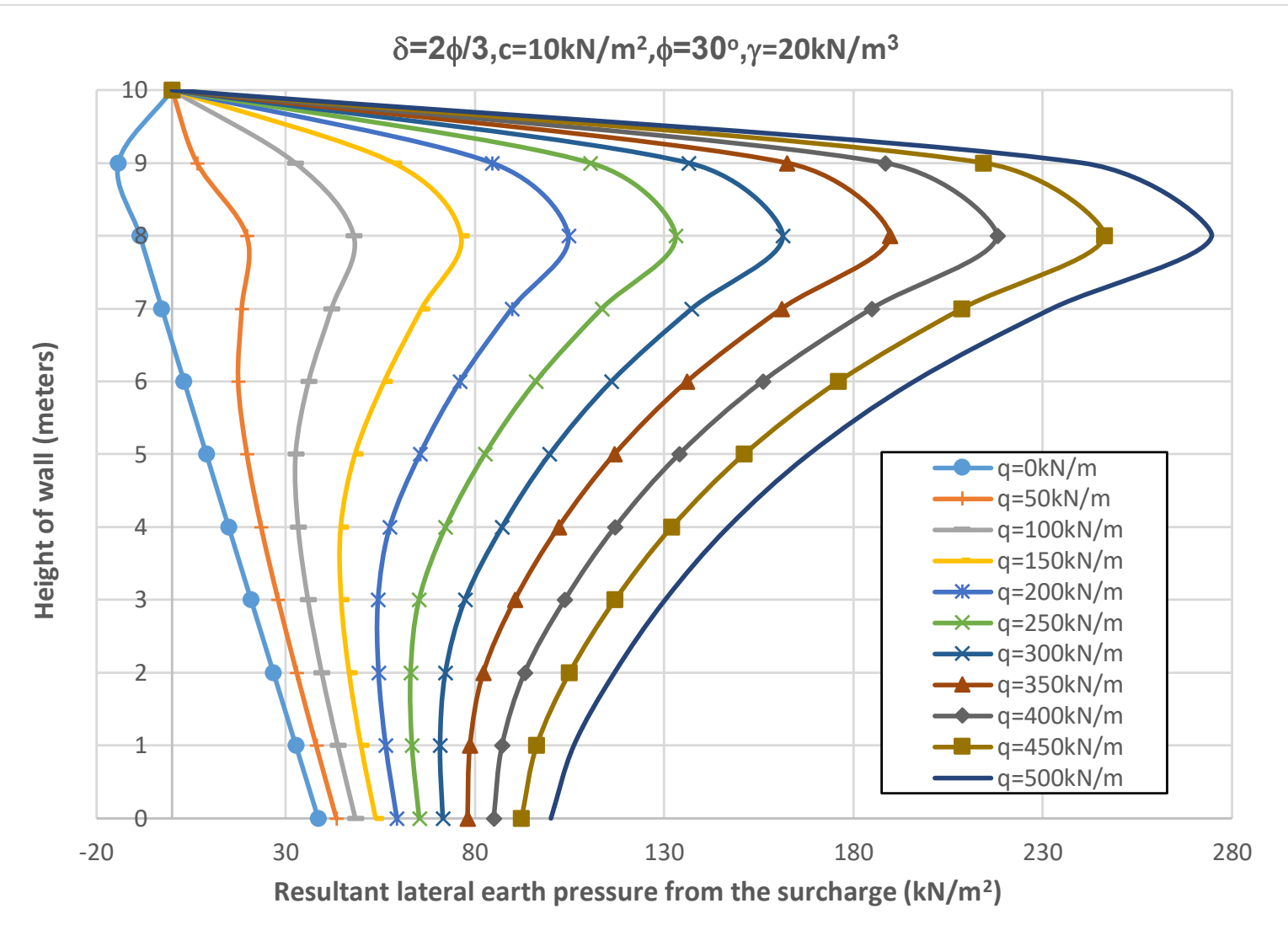

Figure 9: Distribution of total active pressure across the wall for different values of linear surcharge for $\phi=$ 30 and $\delta=2 \phi / 3$.

3.3. Comparison of the results of the proposed method with the results of other researchers and codes:

Table 1 compares the results of the proposed method for a retaining wall with linear surcharge effect with the results of four methods including (Mojtaba Ahmadabadi \& Faghirizadeh, 2017), (Farzaneh et al., 2014), (Ghanbari \& Taheri, 2012) and (Motta, 1994) under equal conditions. The results are considered in three cases: surcharge 20,50, and $100(\mathrm{kN} / \mathrm{m})$ and for $\phi=30 \mathrm{o}$ and $\mathrm{C}=0 \mathrm{kN} / \mathrm{m} 2$. The results of the proposed method are closely related to (Mojtaba Ahmadabadi \& Faghirizadeh, 2017) and (Farzaneh et al., 2014) and (Motta, 1994), with a difference of less than 0.2 percent, but about 7 percent in surcharge conditions of $\mathrm{q}=$ $100(\mathrm{kN} / \mathrm{m})$ and about $1.2 \%$ at $\mathrm{q}=20(\mathrm{kN} / \mathrm{m})$ with (Ghanbari \& Taheri, 2012).

Table 1: Comparison of the proposed method results of total pressure on the wall with the results of other researchers

\begin{tabular}{lccccc}
\hline \multirow{2}{*}{ Pas $(\mathrm{kN} / \mathrm{m} 2)$} & $\begin{array}{c}\text { Proposed } \\
\text { method }\end{array}$ & $\begin{array}{c}\text { (Mojtaba Ahmadabadi } \\
\text { \& Faghirizadeh, 2017) }\end{array}$ & $\begin{array}{c}\text { (Farzaneh et } \\
\text { al., 2014) }\end{array}$ & $\begin{array}{c}\text { (Ghanbari \& } \\
\text { Taheri, 2012) }\end{array}$ & $\begin{array}{c}\text { (Motta, } \\
\text { 1994) }\end{array}$ \\
\hline $\mathrm{q}=20(\mathrm{kN} / \mathrm{m})$ & 318.34 & 318.34 & 319 & 315.08 & 318.9 \\
\hline $\mathrm{q}=50(\mathrm{kN} / \mathrm{m})$ & 333.8 & 333.8 & 335 & 321.69 & 334.9 \\
\hline $\mathrm{q}=100(\mathrm{kN} / \mathrm{m})$ & 361.04 & 361.04 & 366 & 334.73 & 361.6 \\
\hline
\end{tabular}


In table 2, the proposed method results of the angle of the failure wedge were evaluated using (Mojtaba Ahmadabadi \& Faghirizadeh, 2017), (Ghanbari \& Taheri, 2012) and (Motta, 1994) methods in equal conditions for $\phi=20$ and $\phi=30$ respectively.

Table 2: Comparison of the proposed method results of the angle of failure wedge with the results of other researchers

\begin{tabular}{|c|c|c|c|c|c|c|c|c|}
\hline \multirow{3}{*}{$\begin{array}{l}\text { Angle of } \\
\text { failure wedge } \\
\text { (degree) }\end{array}$} & \multicolumn{8}{|c|}{$\gamma=20\left(\mathrm{kN} / \mathrm{m}^{3}\right), \delta=10^{\circ}, \mathrm{x}=4 \mathrm{~m}, \mathrm{H}=10 \mathrm{~m}, \mathrm{C}=0 \mathrm{kN} / \mathrm{m}^{2}$} \\
\hline & \multicolumn{2}{|c|}{ Proposed method } & \multicolumn{2}{|c|}{$\begin{array}{l}\text { (Mojtaba Ahmadabadi } \\
\text { \& Faghirizadeh, 2017) }\end{array}$} & \multicolumn{2}{|c|}{$\begin{array}{c}\text { (Ghanbari \& } \\
\text { Taheri, 2012) }\end{array}$} & \multicolumn{2}{|c|}{ (Motta, 1994) } \\
\hline & $\phi=30$ & $\phi=20$ & $\phi=30$ & $\phi=20$ & $\phi=30$ & $\phi=20$ & $\phi=30$ & $\phi=20$ \\
\hline $\mathrm{q}=20(\mathrm{kN} / \mathrm{m})$ & 59 & 52 & 59 & 52 & 57.2 & 51.9 & 57.3 & 51.4 \\
\hline $\mathrm{q}=50(\mathrm{kN} / \mathrm{m})$ & 60 & 53 & 60 & 53 & 59.7 & 53.3 & 58.1 & 52.1 \\
\hline $\mathrm{q}=100(\mathrm{kN} / \mathrm{m})$ & 62 & 56 & 62 & 56 & 61.6 & 55.7 & 59 & 52.9 \\
\hline
\end{tabular}

The results of this comparison with the three types of surcharge and two types of the angle of internal friction are presented in Table 3 to compare the results with regard to the cohesion effect Ghanbri and Taheri (2012). The difference in results increase with an increase in the angle of friction, which varies between $0.1 \%$ and $5 \%$.

Table 3: Comparison of the proposed method results of total pressure on the wall with the results of (Ghanbari \& Taheri, 2012) with cohesion effect

\begin{tabular}{lcccccccc}
\hline & \multicolumn{4}{c}{$\gamma=20\left(\mathrm{kN} / \mathrm{m}^{3}\right), \delta=10^{\circ}, \mathrm{x}=4 \mathrm{~m}, \mathrm{H}=10 \mathrm{~m}, \mathrm{C}=\mathrm{kN} / \mathrm{m}^{2}$} \\
\cline { 2 - 9 } $\operatorname{Pas}(\mathrm{kN} / \mathrm{m} 2)$ & \multicolumn{4}{c}{ Proposed method } & \multicolumn{2}{c}{$\phi=20$} & \multicolumn{2}{c}{$\phi=30$} \\
\cline { 2 - 9 } & $\mathrm{C}=0$ & $\mathrm{C}=10$ & $\mathrm{C}=0$ & $\mathrm{C}=10$ & $\mathrm{C}=0$ & $\mathrm{C}=10$ & $\mathrm{C}=0$ & $\mathrm{C}=10$ \\
\hline $\mathrm{q}=20(\mathrm{kN} / \mathrm{m})$ & 457.96 & 329.86 & 318.34 & 211.48 & 457.58 & 326.88 & 315.08 & 205.86 \\
\hline $\mathrm{q}=50(\mathrm{kN} / \mathrm{m})$ & 475.44 & 348.21 & 333.8 & 227.38 & 472.42 & 357.89 & 321.69 & 212.059 \\
\hline $\mathrm{q}=100(\mathrm{kN} / \mathrm{m})$ & 506.5 & 380.42 & 361.04 & 255.25 & 491.45 & 360.77 & 334.73 & 223.24 \\
\hline
\end{tabular}

Table 4 compares the results of the proposed method for a retaining wall with no surcharge and in cohesivefrictional soil with six other methods under equal conditions. In comparison, two types of linear and circular failure wedges have been used. The results are considered in three cohesion states of 0 to 20 and for $\phi=20^{\circ}$ and $\phi=30^{\circ}$. The results show the convergence between the proposed method and the other six methods.

Table 4: Comparison of the results of total pressure on the wall and the angle of the failure wedge with the results of other researchers without surcharge effect

\begin{tabular}{|c|c|c|c|c|c|c|c|c|c|c|c|c|c|c|c|}
\hline & & \multicolumn{14}{|c|}{$\mathrm{q}=0(\mathrm{kN} / \mathrm{m}), \delta=10$} \\
\hline & & \multicolumn{2}{|c|}{ Proposed method } & \multicolumn{2}{|c|}{$\begin{array}{l}\text { Ahmadabadi } \\
\text { et al. }(2017)\end{array}$} & \multicolumn{2}{|c|}{$\begin{array}{c}\text { (Ghanbari \& } \\
\text { Taheri, 2012) }\end{array}$} & \multicolumn{2}{|c|}{$\begin{array}{l}\text { Ahmadabadi and } \\
\text { Ghanbari (2009) }\end{array}$} & \multicolumn{2}{|c|}{ (Cheng, 2003) } & \multicolumn{2}{|c|}{$\begin{array}{c}\text { (B. M. Das \& } \\
\text { Puri, 1996) }\end{array}$} & \multicolumn{2}{|c|}{$\begin{array}{c}\text { Coulomb } \\
\text { method }\end{array}$} \\
\hline & & $\mathrm{Pa}$ & $\beta$ & $\mathrm{Pa}$ & $\beta$ & $\mathrm{Pa}$ & $\beta$ & $\mathrm{Pa}$ & $\beta$ & $\mathrm{Pa}$ & $\beta$ & $\mathrm{Pa}$ & $\beta$ & $\mathrm{Pa}$ & $\beta$ \\
\hline \multirow{2}{*}{$\begin{array}{l}\mathrm{C}=0 \\
\mathrm{kN} / \mathrm{m}^{2}\end{array}$} & $\phi=20$ & 446.74 & 446.74 & 446.74 & \multirow{6}{*}{ 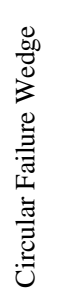 } & 446.74 & 446.74 & 446.74 & 446.74 & 446.74 & 446.74 & 446.74 & 446.74 & 446.74 & 51 \\
\hline & $\phi=30$ & 308.45 & 308.45 & 308.45 & & 308.45 & 308.45 & 308.45 & 308.45 & 308.45 & 308.45 & 308.45 & 308.45 & 308.45 & 58 \\
\hline \multirow{2}{*}{$\begin{array}{l}\mathrm{C}=10 \\
\mathrm{kN} / \mathrm{m}^{2}\end{array}$} & $\phi=20$ & 318.03 & 318.03 & 318.03 & & 318.03 & 318.03 & 318.03 & 318.03 & 318.03 & 318.03 & 318.03 & 318.03 & 318.03 & - \\
\hline & $\phi=30$ & 201.23 & 201.23 & 201.23 & & 201.23 & 201.23 & 201.23 & 201.23 & 201.23 & 201.23 & 201.23 & 201.23 & 201.23 & - \\
\hline \multirow{2}{*}{$\begin{array}{l}\mathrm{C}=20 \\
\mathrm{kN} / \mathrm{m}^{2}\end{array}$} & $\phi=20$ & 190.43 & 190.43 & 190.43 & & 190.43 & 190.43 & 190.43 & 190.43 & 190.43 & 190.43 & 190.43 & 190.43 & 190.43 & - \\
\hline & $\phi=30$ & 94.37 & 94.37 & 94.37 & & 94.37 & 94.37 & 94.37 & 94.37 & 94.37 & 94.37 & 94.37 & 94.37 & 94.37 & - \\
\hline
\end{tabular}

In these codes, soil parameters are not considered and the soil is studied as elastic, whereas in the proposed method, the soil parameters such as the angle of internal friction and the angle of friction between the soil 
and the wall are considered. Table 5 compares the results of the proposed method with different codes. The reason for the difference in results in this table is the lack of consideration of the soil specifications, including the angle of internal friction and the angle of friction between the soil and the wall in these codes. As it is known, the results can be approximated by changing the soil specifications in the proposed method.

Table 5: Comparison of the proposed method results of excess pressure under surcharge effect and (Ghanbari \& Taheri, 2012) and codes

\begin{tabular}{|c|c|c|c|c|c|c|c|c|c|c|}
\hline \multirow{4}{*}{$\mathrm{P}_{\mathrm{aq}}\left(\mathrm{kN} / \mathrm{m}^{2}\right)$} & \multicolumn{10}{|c|}{$\mathrm{x}=4 \mathrm{~m}, \mathrm{H}=10 \mathrm{~m}, \quad \mathrm{~g}=20 \mathrm{kN} / \mathrm{m}^{3}, \mathrm{C}=0 \mathrm{kN} / \mathrm{m}^{2}$} \\
\hline & \multicolumn{6}{|c|}{ Proposed method } & \multicolumn{2}{|c|}{$\begin{array}{l}\text { (Ghanbari \& } \\
\text { Taheri, 2012) }\end{array}$} & \multirow{3}{*}{$\begin{array}{l}\text { USACE } \\
(2005)\end{array}$} & \multirow{3}{*}{$\begin{array}{l}\text { (AASHT } \\
\text { O, 2002) }\end{array}$} \\
\hline & \multicolumn{3}{|c|}{$\phi=20$} & \multicolumn{3}{|c|}{$\phi=40$} & & \multirow{2}{*}{$\phi=30$} & & \\
\hline & $\delta=0$ & $\delta=\phi / 3$ & $\delta=\phi$ & $\delta=0$ & $\delta=\phi / 3$ & $\delta=\phi$ & & & & \\
\hline $\mathrm{q}=50(\mathrm{kN} / \mathrm{m})$ & 55.9 & 49.79 & 42.2 & 26.8 & 24.4 & 24.1 & 24.67 & 12.72 & 36.07 & 26.78 \\
\hline $\mathrm{q}=100(\mathrm{kN} / \mathrm{m})$ & $\begin{array}{c}111 . \\
8\end{array}$ & 99.58 & 84.5 & 53.6 & 48.8 & 48.2 & 43.08 & 25.05 & 54.76 & 54 \\
\hline
\end{tabular}

The results of this study are accomplished with four sample numerical models with ABAQUS finite element software (6.14). ABAQUS software is one of the most powerful simulation software in a limited run. The geometry of the model is 2D and as deformable type. Elastic and plastic specification, soil and wall are selected according to Table 6 . The parameters c, $\varphi$ and $\psi$ are the cohesion, internal friction angle, and angle of expansion of the materials in Mohr-Coulomb's behavioral model. The mesh generation is selected of the Tri-Element type. The results show the appropriate convergence between the proposed method and ABAQUS software and the maximum difference of results is about $5.8 \%$.

Table 6: Comparison of the results of the proposed method with numerical modeling with (Abaqus, 2014) software.

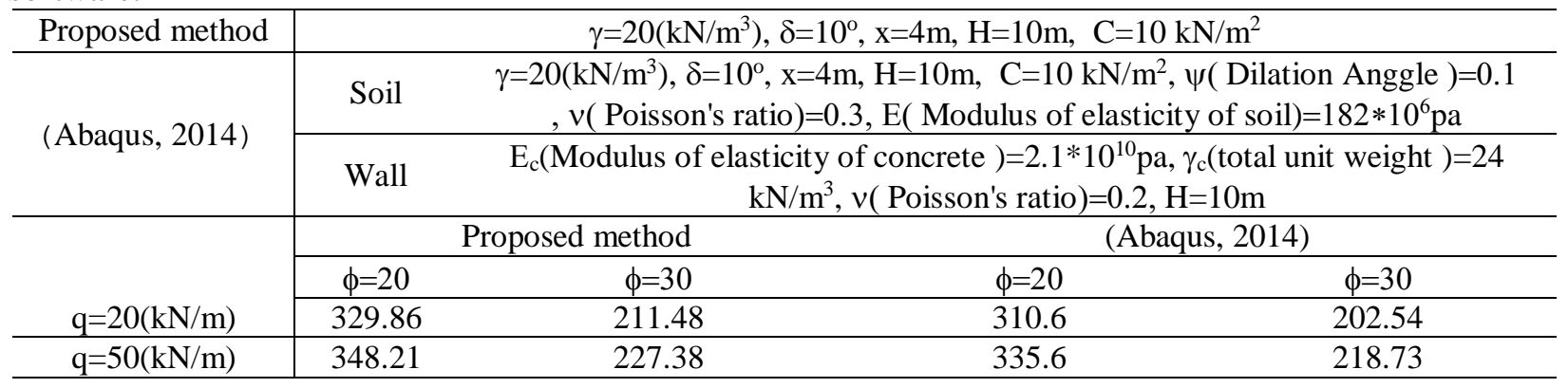

\section{CONCLUSIONS}

In this research, the following results can be extracted:

1. The proposed method has provided a simple solution, using the limit equilibrium method with direct approach to the effect of soil and surcharge for calculating the active pressure on the wall with linear surcharge effect in cohesive-frictional soils. It has the ability to provide three types of soil active pressure coefficient with linear surcharge effect, the angle of failure wedge, distribution of total pressure on the wall and the distribution of excess pressure for different soil specifications, including cohesion and angle of internal friction. In the previous methods, the cohesion and the angle of friction between the soil and the wall are neglected, or the proposed methods require a complex and long-term solution. 
2. Dimensionless diagrams have been proposed where the variations of the angle of internal friction of the soil, linear surcharge, the angle of friction between the soil and the wall and cohesion are considered. The results indicate that the increase of the angle of internal friction of the soil and cohesion will reduce the active pressure coefficient in a nonlinear way unlike a linear surcharge, which increases the active pressure of the soil and ultimately increases the Kas coefficient. Also, by increasing the surcharge distance from the wall, the pressure on the wall decreases. These changes start with a surcharge distance from the wall from a maximum limit and end at a minimum. By increasing the angle of internal friction of the soil, the maximum impact distance of the surcharge is reduced. In addition, with the increase in the amount of surcharge, the pressure on the wall increases, and the distance between the surcharge and this difference decreases and eventually becomes zero.

3. In this research, a diagram is presented that expresses the surface that the active pressure coefficient changes with respect to the surcharge distance. The lower limit of each diagram expresses the minimum active pressure coefficient (kas ( $\mathrm{min})$ ) at the minimum surcharge distance, whereas the upper limit indicates the maximum active preassure coefficient $(\operatorname{kas}(\max ))$ at the maximum surcharge distance from the wall. The diagrams are plotted for different surcharges and cohesion, and interpolation can be used for other values.

4. With the presented equations and diagrams, the angles of failure wedge can be obtained with linear surcharge effect, and the results show that increasing linear surcharge and angle of internal friction of the soil and cohesion increase the angle of failure wedge.

5. In the proposed method, it is possible to plot the excess pressure distribution due to the surcharge and the distribution of the total active pressure on the wall, which can be calculated by calculating the surface below this diagram to calculate the excess pressure and total pressure on the wall. Increasing the angle of internal friction of the soil and cohesion always reduces stress distribution. Furthermore, increasing surcharge causes inflation and non-linearity in the stress distribution diagram.

6. The results of the proposed method for the retaining wall have been compared with the results of the codes and the numerical software (Abaqus, 2014) and four methods including (Mojtaba Ahmadabadi \& Faghirizadeh, 2017), (Farzaneh et al., 2014), (Ghanbari \& Taheri, 2012) and (Motta, 1994) in equal conditions with linear surcharge effect. In order to verify the angle of failure wedge, the results of (Mojtaba Ahmadabadi \& Faghirizadeh, 2017), (Ghanbari \& Taheri, 2012) and (Motta, 1994) have been evaluated. It has also been compared to six other methods for retaining wall without surcharge effect and in cohesivefrictional soil under equal conditions. In comparison, two types of linear and circular failure wedges have been used.

\section{REFERENCES}

AASHTO. (2002). Standard specifications for highway bridges. 17th ed. Washington, DC, USA: American Association of State Highway and Transportation Officials.

Abaqus, F. (2014). Dassault Systemes Simulia Corporation. Providence, Rhode Island, USA.

Ahmadabadi, M., Faghirizadeh, M., K, Hosseini, S., \& Naghibi, M. (2017). Determination of active pressure exerted on retaining walls with a circular failure wedge using the horizontal slices method in cohesive-frictional soil. Journal of Engineering and Applied Sciences, 12(19), 6. doi:10.3923/jeasci.2017.5012.5017v

Ahmadabadi, M., \& Faghirizadeh, M. K. (2017). Design Diagrams for the Analysis of Active Pressure on Retaining Walls with the Effect of Line Surcharge. Advances in Civil Engineering, 2017, 9. doi:10.1155/2017/9897658

Ahmadabadi, M. and M.K. Faghirizadeh. (2010). MATLAB Software Training for Engineers. Naghoos Publication. 
Ahmadabadi, M., \& Ghanbari, A. (2009). New procedure for active earth pressure calculation in retaining walls with reinforced cohesive-frictional backfill. Geotextiles and Geomembranes, 27(6), 456-463. doi:https://doi.org/10.1016/j.geotexmem.2009.06.004

Basha, B. M., \& Basudhar, P. K. (2010). Pseudo Static Seismic Stability Analysis of Reinforced Soil Structures. Geotechnical and Geological Engineering, 28(6), 745-762. doi:10.1007/s10706-010-9336-2

Cheng, Y. M. (2003). Seismic lateral earth pressure coefficients for $\mathrm{c}-\varphi$ soils by slip line method. Computers and Geotechnics, 30(8), 661-670. doi:https://doi.org/10.1016/j.compgeo.2003.07.003

Coulomb, C. A. (1773). Essai sur une application des regles de maximis et minimis a quelques problemes de statique relatifs a l'architecture (essay on maximums and minimums of rules to some static problems relating to architecture).

Das, B. M. (1992). Principles of soil dynamics. Boston: PWS-Kent Pub. Co.

Das, B. M., \& Puri, V. K. (1996). Static and dynamic active earth pressure. Geotechnical \& Geological Engineering, 14(4), 353-366. doi:10.1007/bf00421949

Esmaeili, M., \& Fatollahzadeh, A. (2013). Effect of Train Live Load on Railway Bridge Abutments. Journal of Bridge Engineering, 18(6), 576-583. doi:10.1061/(asce)be.1943-5592.0000393

Farzaneh, O., Askari, F., \& Fatemi, J. (2014). Active earth pressure induced by strip loads on a backfill. International Journal of Civil Engineering, 12(4), 281-291.

Ghanbari, A., \& Taheri, M. (2012). An analytical method for calculating active earth pressure in reinforced retaining walls subject to a line surcharge. Geotextiles and Geomembranes, 34, 1-10. doi:https://doi.org/10.1016/j.geotexmem.2012.02.009

Greco, V. R. (1999). ACTIVE EARTH THRUST ON CANTILEVER WALLS IN GENERAL CONDITIONS. Soils and Foundations, 39(6), 65-78. doi:10.3208/sandf.39.6_65

Greco, V. R. (2003). PSEUDO-STATIC ANALYSIS FOR EARTH THRUST COMPUTATIONS. Soils and Foundations, 43(2), 135-138. doi:10.3208/sandf.43.2_135

Greco, V. R. (2005). Active earth thrust by backfills subject to a line surcharge. Canadian Geotechnical Journal, 42(5), 1255-1263. doi:10.1139/t05-038

Greco, V. R. (2006). Lateral Earth Pressure due to Backfill Subject to a Strip of Surcharge. Geotechnical \& Geological Engineering, 24(3), 615-636. doi:10.1007/s10706-005-2009-x

Han, S., Gong, J., \& Zhang, Y. (2016). Earth pressure of layered soil on retaining structures. Soil Dynamics and Earthquake Engineering, 83, 33-52. doi:https://doi.org/10.1016/j.soildyn.2015.12.015

Motta, E. (1994). Generalized Coulomb Active-Earth Pressure for Distanced Surcharge. Journal of Geotechnical Engineering, 120(6), 1072-1079. doi:10.1061/(ASCE)0733-9410(1994)120:6(1072)

Ouyang, C.-j., Xu, Q., He, S.-m., Luo, Y., \& Wu, Y. (2013). A generalized limit equilibrium method for the solution of active earth pressure on a retaining wall. Journal of Mountain Science, 10(6), 1018-1027. doi:10.1007/s11629-0132576-x

Pain, A., Choudhury, D., \& Bhattacharyya, S. K. (2017). Seismic passive earth resistance using modified pseudodynamic method. Earthquake Engineering and Engineering Vibration, 16(2), 263-274. doi:10.1007/s11803-017-03811 
Rankine, W. J. M. (1857). II. On the mathematical theory of the stability of earth-work and masonry. Proceedings of the Royal Society of London(8), 60-61.

YILDIZ, E., OZYAZICIOGLU, M. H., \& OZKAN, M. Y. (2010). Lateral Pressures on Rigid Retaining Walls: A Neural Network Approach. Gazi University Journal of Science, 23(2), 201-210.

\section{SEMBLANCE OF THE AUTHORS}

Mojtaba Ahmadabadi: He is a Faculty Member at Shiraz Art Institute of High Education, Shiraz, Iran

Mohammad Karim Faghirizadeh: He is a Faculty Member at Shiraz Art Institute of High Education, Shiraz, Iran 